\title{
Understanding CSR- Its History and the Recent Developments
}

\author{
Neelam Jhawar ${ }^{1}$, Shasta Gupta ${ }^{2}$ \\ ${ }^{1}$ Assistant Professor Department of Commerce IP College for Women University of Delhi 5807/6, DhaniNiwas, \\ Kamla Nagar, Delhi - 110007 \\ ${ }^{2}$ Assistant Professor Department of Commerce Sri Aurobindo College (Morning) University of Delhi 5807/6, \\ DhaniNiwas, Kamla Nagar, Delhi - 110007
}

\begin{abstract}
All the citizens of a country have certain rights and duties. Citizens include not only natural persons but also the companies. Companies should operate as good responsible corporate citizens. Modern corporations cannot shirk their responsibilities because their activities exert a tri-dimensional impact (economic, social, and environmental) on the society. A socially responsible firm not only meets these needs of the society but also enhances its goodwill and creates a long term and sustainable market for its products. This is the concept of corporate social responsibility. This paper attempts to understand the evolution of the concept of corporate social responsibility and its current interpretations. It was found that United States of America pioneered the concept of corporate social responsibility. From just being meant to refer to philanthropy, CSR has come a long way to include the impact of companies' activities on the environment, economy, society and all the stakeholders. An important term associated with the broader meaning of CSR is 'triple bottom line', which means taking care of people, planet and profit.
\end{abstract}

Keywords: Companies, CSR, evolution, history, developments

\section{Introduction}

Economic criteria alone cannot justify the existence of business organizations. Social, moral and ethical aspects of business decisions are as important as economic aspects to judge the success of a business. Business is a part of the society and owes its existence to the society. Naturally, it should function under the overall control and discipline of the society. The society requires every business to perform certain obligations. The performance of such obligations is essential not only for the well-being of the society, but also for the survival and well- being of the business itself. Thus, obligations of a business to the different segments of the society determine its overall objectives. Modern corporations cannot shirk their responsibilities because their activities exert a tri-dimensional impact (economic, social, and environmental) on the society. A socially responsible firm not only meets these needs of the society but also enhances its goodwill and creates a long term and sustainable market for its products. For long time in the past, profit maximization was the sole business objective but this view no more holds good. If companies want to survive and maintain growth in the market, if they want to become market leaders, they have to sacrifice part of the profits in favor of groups other than owners. This outlook recognizes the concept of social responsibility. Managers have begun to realize that they owe responsibility to society as they owe to business enterprises. The objective of a Socially Responsible Organization (SRO) is to influence the process of developing and advocating socially responsible business practices which benefit not only the SRO and its employees, but also the greater community, the economy and the world environment. SROs seek to reshape the way business is done both for profit and not-for-profit areas.

\section{Historical Background Of CSR}

The concept of CSR evolved mainly in the Western countries, most notably the United States of America. The roots of the concept of CSR as it is known today have a long history which indicates that business people have paid increasing attention to the concerns of society. According to ESCAP (2011), in the late nineteenth century, businesses raised concerns on the welfare of their employees and their impact on society in general. With the emergence of the labor movement and spreading of slums triggered by the industrial revolution, businesses started to provide social welfare on a limited scale, including the construction of hospitals and bath houses and provision of food coupons. In the same period, individual business philanthropists became active in the United States (e.g. John D. Rockefeller and Cornelius Vanderbilt). Although the legitimacy of philanthropy was not yet well established, benefits offered by those philanthropists were recognized by local communities and various social groups. The Great Depression in 1929 further strengthened this trend with the introduction of public trusteeship management (in addition to traditional profit-maximizing management). Carroll (2008) highlights business philanthropy in this period as spearheading the development of the CSR concept. However, for all practical purposes, CSR is largely a post-World War II phenomenon and actually did 
not urge in importance until 1960s and beyond (Carroll and Shabana, 2010). Thus, initially CSR was in the form of Philanthropy by the Corporates, but after the 1950s, the concept has undergone a sea change. ${ }^{\mathrm{i}}$

Archie B. Carroll, who is known for the most comprehensive overview of the definitions of CSR from 1950s through the mid-1990s, credits Howard R. Bowen as the Father of Corporate Social Responsibility because his book Social Responsibilities of the Businessman (1953) dealt directly with the concept of Social Responsibility. Thus the concept of CSR officially emerged in the 1950s with publication of Howard R. Bowen's book Social Responsibilities of the Businessman in 1953.

Even before this, although the term CSR was not used, Bernard Dempsey, in his 1949 Harvard Business Review (HBR) article - "The Roots of Business Responsibility," laid out a rationale for responsible business practice. Dempsey provided a philosophical foundation for arguments in an HBR article two months prior by Donald K. David, Dean of the Harvard Graduate School of Business Administration, titled "Business Responsibilities in an Uncertain World." David called upon business leaders to become engaged in public affairs beyond the immediate economic functions of business which they regarded as its fundamental contribution to society. Dempsey provided philosophical foundations arguing the responsibilities of businessmen [apparently no businesswomen were contemplated] arose from four concepts of justice: exchange justice - the trust underlying exchanges in the market; distributive justice - the just relation between the government and individuals; general justice - acceptance of legal frameworks but beyond this to acceptance of ethical obligations; and especially social or contributive justice - the obligation to contribute to the well-being and progress of individuals and society.

Dempsey and David asserted two reasons why businessmen must respond to the obligations of contributive justice. (1) They essentially argued that no man, and no business, is an island. All are in need of a community, a well-functioning community, in order to operate and thrive. (2) They argued that business controls substantial resources and has great capacity to contribute to the progress of society and the well-being of individuals within society. This echoes other arguments that business power brings with it business responsibility. David noted a priority in business obligations: first to make the business effective, second to make the business organization itself a good and just society (a healthy organization), and third to operate in ways that respect and contribute to external communities and organizations - in other words to be constructive. Included in their concept was a responsibility to ensure that competition was fair, that the economic framework was functioning with an eye toward justice, and that broader communities were healthy. Dempsey added that contributive justice is the first principle of economic organization; it imposes a positive obligation upon every economic agent not only to contribute positively to every community of which he is a member but to contribute positively to the formation of necessary communities which do not exist.

Both Dempsey and David argued that the broad spectrum of business leaders, regardless of how they might articulate it, believed in a fundamental obligation to create a just society beyond the immediate boundaries of the business and within which business could operate effectively. They built on a rich dialogue that preceded their writing by many years, and they foreshadowed future debates about business responsibility. ${ }^{\text {ii }}$ The concept of CSR has evolved overtime and the alternative interpretations and approaches that have emerged are shown below in the table:

Table I- Development of CSR concepts

\begin{tabular}{|l|l|l|l|}
\hline Period & Name of Concept & Description & Literature \\
\hline 1950 s-1960 & $\begin{array}{l}\text { Social Responsibility } \\
\text { businessmen }\end{array}$ & $\begin{array}{l}\text { The obligations of businessmen to pursue } \\
\text { policies, to make decisions or to follow lines of } \\
\text { action which are desirable in terms of the } \\
\text { objectives and values of society } \\
\text { Some socially responsible business decisions } \\
\text { can be justified by the long-run economic gain } \\
\text { of the firm, thus paying back for its socially } \\
\text { responsible behavior. } \\
\text { Private contribution to society's economic and } \\
\text { human resources and a willingness on the part } \\
\text { of business to see that those resources were } \\
\text { utilized for broad social ends. }\end{array}$ & Davis (1960) \\
\hline 1960s-1970s & Stakeholder Approach & $\begin{array}{l}\text { Instead of striving only for larger returns to its } \\
\text { shareholders, a responsible enterprise takes into } \\
\text { account the interests of employees, suppliers, } \\
\text { dealers, local communities and the nation as a } \\
\text { whole. } \\
\text { The concept consists of corporate } \\
\text { responsibilities (i.e., economic, legal, ethical } \\
\text { and philanthropic), social issues of business } \\
\text { (e.g., labor standards, human rights, } \\
\text { environment protection and anticorruption) and } \\
\text { corporate actions (e.g., reactive, defensive, }\end{array}$ & \\
\hline & Carroll (1979)
\end{tabular}




\begin{tabular}{|c|c|c|c|}
\hline & & accommodative and proactive). & \\
\hline 1980s-1990s & $\begin{array}{l}\text { Three-dimensional model of } \\
\text { principles, policies and processes } \\
\text { Institutional Framework and } \\
\text { extended corporate actions }\end{array}$ & $\begin{array}{l}\text { Integration of the principles of corporate } \\
\text { responsibility, the policies of social issue } \\
\text { management and the process of action into an } \\
\text { evolving system. } \\
\text { Four types of corporate responsibilities (i.e., } \\
\text { economic, legal, ethical and philanthropic) } \\
\text { were linked to three institutional levels (i.e., } \\
\text { legal, organizational and individual), while } \\
\text { corporate actions are extended to assessment, } \\
\text { stockholder management and implementation } \\
\text { management. }\end{array}$ & $\begin{array}{l}\text { Wartick and Cochran } \\
(1985)\end{array}$ \\
\hline $2000 \mathrm{~s}$ & $\begin{array}{l}\text { Three-domains approach } \\
\text { New Concept }\end{array}$ & $\begin{array}{l}\text { Three domains of corporate responsibilities: } \\
\text { economic, legal and ethical. } \\
\text { A process to integrate social, environmental, } \\
\text { ethical, human rights and consumer concerns } \\
\text { into business operations and core strategy in } \\
\text { close corporation with the stakeholders. }\end{array}$ & $\begin{array}{l}\begin{array}{l}\text { Schwartz and Carroll } \\
(2003)\end{array} \\
\begin{array}{l}\text { European } \\
(2011)\end{array}\end{array}$ \\
\hline
\end{tabular}

Adapted from: Developments in the Concept of CSR (Chapter II, ESCAP, 2011)

With the entry of the twenty-first century, the scope of CSR has grown wider, and the CSR community has focused more on the implementation of CSR initiatives, while the refinement of the CSR concept has received less attention.

\section{The Changing Environment Of Business}

Understanding the history of CSR also requires us to understand the changes that influenced the approach to CSR and led to its broadening scope. Let us, therefore, look at those factors which have changed the environment of business-

Globalization of the economy and even the operations of smaller companies is a fundamental factor. Operating globally confronts companies with a wide range of new issues (cultural and regulatory differences, labor and child labor standards, bribery and corruption, health crises, human rights, deforestation, etc.).

The explosive development of civil society organizations (CSOs) and nongovernmental organizations (NGOs) which often challenge corporate behavior has compelled companies to respond. NGOs at the center of this grassroots CSR movement are extremely heterogeneous in terms of goals - ranging from outright attacks on the fundamental power of corporations to efforts to enhance beneficial and reduce detrimental impacts, and equally heterogeneous in terms of strategies deployed - ranging from confrontation to engagement, from standalone operations to highly sophisticated coalitions among NGOs.

Political pressure has prompted initiatives in governmental and intergovernmental organizations. Proposals have arisen within the United Nations, the International Labor Organization (ILO), the OECD, the governments of the United Kingdom, France, and the European Union - to name only a few. Even though it has resisted linking economic and social concerns, the WTO has also been a focal point for debate about the scope of business responsibilities since the WTO sets the rules for the global trade. The range of issues is equally diverse - environment, labor rights, human rights, trade, corruption, corporate governance, health, transparency and disclosure, etc. And increasingly, governments of developing nations are weighing in, sometimes in opposition to CSR initiatives. Companies have responded sometimes defensively and sometimes with efforts to demonstrate that voluntary approaches will achieve better results.

Although often imperfectly expressed through opinion polls, societal values today, more so than

60 years ago, appear to emphasize the responsibility of companies to improve society and to improve the environment. Shifts in public values and opinion can be related to the growth of

NGOs, changing informal standards as well as legal prescriptions for business conduct, emergence of causerelated marketing, and linkage between a company's reputation and its giving and community involvement. However, it must be acknowledged that what people say when polled and what they do as customers at the point of sale may diverge. (For example, they may state that they prefer responsible products but buy solely on price). Nonetheless, many companies factor public expectations about CSR into a wide range of business practices. MORI (Market Opinion Research International - the largest market research company in Great Britain), Gallup, Harris and other polling organizations can provide data on the public's changing values and expectations.

Socially Responsible Investment (SRI) grew out of grassroots efforts to restrict investment in South Africa as a means of opposing apartheid. Other issues capturing the attention of "ethical" investors have been: environment, military armaments, alcohol, tobacco and community or economic development - among others. SRI investors and analysts have increasingly pressured companies to disclose social, environmental and ethical risks that may impact business and to report regularly on social and environmental as well as financial results the "triple bottom line." This pressure led to efforts to develop common reporting and measurement 
frameworks. It has also raised questions about what is and is not "material" (materiality is the question of when an event or measurement becomes a significant factor in a company's financial statement).

While some codes and standards have emerged from business leaders themselves (e.g., the Caux Round Table Principles for Business), many codes are products of consumer and NGO advocacy and public dissatisfaction with corporate conduct. In some instances, companies have become partners in multi-sector initiatives to develop standards. Some are grounded in governmental conventions such as the UN Declaration on Human Rights or the several ILO conventions on labor. Currently under consideration at the UN is the Draft Norms on the Responsibilities of Transnational Corporations and Other Business Enterprises with Regard to Human Rights. Examples: Standards advanced by NGOs, religious groups, business, and others (some with government involvement) include: The Sullivan Principles, the CERES Principles, the Bellagio Principles Toward Sustainable Development, the Minnesota Principles, Voluntary Principles on Security and Human Rights, the White House Apparel Industry Code of Conduct, and the UN Global Compact - to note only a few. ${ }^{\text {iv }}$

\section{CSR - The Concept Today!}

CSR has no universal definition. CSR as it exists today typically has economic, social and environmental dimensions.

According to World Business Council for Sustainable Development (WBCSD), 1999 "Corporate Social Responsibility is the continuing commitment by business to behave ethically and contribute to economic development while improving the quality of life of the workforce and their families as well as the local community and society at large."

According to United Nations Research Institute for Social Development (UNRSD), 2003 “At the core of this 'corporate social responsibility' (CSR) agenda are specific policies and practices involving codes of conduct, environmental management systems, stakeholder dialogues, community investment and philanthropy, as well as reporting, auditing and certification related to social and environmental aspects."

CSR today embraces the Triple Bottom Line (TBL) concept. TBL concept considers 3Ps, that is, People- the social bottom line, Planet- the ecological bottom line, and Profit- the economic bottom line. It encourages the corporations to take a more objective look at their impacts on people, and planet, rather than focusing on profit alone. Today more and more companies are taking up this new way of addressing the intangible concepts of CSR through TBL which emphasizes on data collection, analysis, and decision making using economic, environmental and social performance information. This concept requires the companies to look at not only what it should do with the profits, but also how it made its profits with the focus the impact of its operations on its various stakeholders. ${ }^{\mathrm{v}}$

As businesses face intensified challenges, including rapid globalization, increasing environmental concerns and mounting pro-poor needs, there has been a growing need for the adoption of result-based CSR management and stringent evaluation of CSR Performance (ESCAP, 2009). These trends suggest that businesses integrate CSR into their core operations throughout the value chains they are part of at both national and global levels. As Peter Drucker (1984) noted that 'But the proper 'social responsibility' of business is to tame the dragon, that is to turn a social probleminto economic opportunity and economic benefit, into productive capacity, into human competence, intowell-paid jobs, and into wealth.",vi

\section{Conclusion}

As businesses face intensified challenges, including rapid globalization, increasing environmental concerns and mounting pro-poor needs, there has been a growing need for the adoption of result-based CSR management and stringent evaluation of CSR Performance (ESCAP, 2009). These trends suggest that businesses integrate CSR into their core operations throughout the value chains they are part of at both national and global levels. As Peter Drucker (1984) noted that 'But the proper 'social responsibility' of business is to tame the dragon, that is to turn a social probleminto economic opportunity and economic benefit, into productive capacity, into human competence, intowell-paid jobs, and into wealth." CSR is a tool to achieve Sustainable Development. The concept overlaps with concepts such as Corporate Citizenship, Corporate Philanthropy, Business Ethics, and Corporate Sustainability etc.

For long time in the past, profit maximization was the sole business objective but this view no more holds good. If companies want to survive and maintain growth in the market, if they want to become market leaders, they have to sacrifice part of the profits in favor of groups other than owners.In India, For Building a better future the Indian government has brought in to affect new CSR guidelines requiring companies to spend $2 \%$ of their net profit on social development. India is the first country in the world to mandate corporate social responsibility. Spending $2 \%$ on CSR is a lot, especially for companies that are trying to scale up in these difficult times. It must not be imposed. What it turns out to be will be seen in the years to come. Notwithstanding this, it has been a welcome step. 
It was found that United States of America pioneered the concept of corporate social responsibility. From just being meant to refer to philanthropy, CSR has come a long way to include the impact of companies' activities on the environment, economy, society and all the stakeholders. An important term associated with the broader meaning of CSR is 'triple bottom line', which means taking care of people, planet and profit.

\section{Endnotes}

${ }^{\mathrm{i}}$ Economic and Social Commission for Asia and the Pacific (2011).Developments in the concept of Corporate Social Responsibility (CSR). Available at http://www.unescap.org/our-work/trade-investment

ii Carroll, A.B. \&Shabana, K.M. (2010). The Business Case for Corporate Social Responsibility: A Review of Concepts, Research and Practice. Available at http://papers.ssrn.com/sol3/papers.cfm?abstract id=1537406

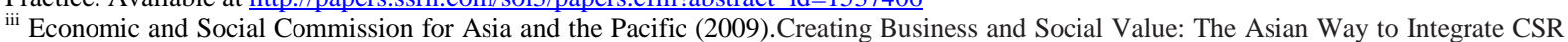
into Business Strategies. Available at http://www.unescap.org/our-work/trade-investment

iv Center for Ethical Business Cultures (2005). Corporate Social Responsibility, The Shape of History, 1945-2004. Available at http://www.cebcglobal.org/knowledge-center/publications/

${ }^{v}$ Sharma, J. P. (2013). Corporate Governance, Business Ethics \& CSR. New Delhi: Ane Books Pvt. Ltd.

${ }^{v i}$ Economic and Social Commission for Asia and the Pacific (2009).Creating Business and Social Value: The Asian Way to Integrate CSR into Business Strategies. Available at http://www.unescap.org/our-work/trade-investment

\section{References}

[1] Article on India's new CSR law sparks debate among NGOs and businesses (2014). Available at http://www.theguardian.com/sustainable-business/india-csr-law-debate-business-ngo

[2] Birch, D. \& Batten, J. (2002). Corporate Citizenship in Australia: A Survey of Corporate Australia. Available at http://dro.deakin.edu.au/eserv/DU.../birch-corporatecitizenshipinaust-2002.pdf

[3] Carroll, A.B. (1991) The Pyramid of Corporate Social Responsibility: Toward the Moral

[4] Management of Organizational Stakeholders. Business Horizons.Available at wwwrohan.sdsu.edu/faculty/dunnweb/rprnts.pyramidofcsr.pdfCarroll, A.B. (2008). A History of Corporate SociaResponsibility:Concepts and Practices.Available http://www.academia.edu/860777/A_history_of_corporate_social_responsibility_concepts_and_practices

[5] Carroll, A.B. \&Shabana, K.M. (2010). The Business Case for Corporate Social Responsibility: A Review of Concepts, Research and Practice. Available at http://papers.ssrn.com/sol3/papers.cfm?abstract id=1537406

[6] Carroll, A.B.\&Buchholtz, A.K. (2012).Business and Society: Ethics, Sustainability, and Stakeholder Managaement. South-Western Cengage Learning.Available at http://www.nelsonbrain.com/content/carroll53168 0538453168 02.01_chapter01.pdf.

[7] Center for the study of Regulated Industries, (2003). Corporate Social Responsibility- A role in Government Policy and Regulation.

[8] Available at www.bath.ac.uk/cri/pubpdf/Research_Reports/16_Bichta.pdf

[9] Center for Ethical Business Cultures (2005). Corporate Social Responsibility, The Shape of History, 1945-2004. Available at http://www.cebcglobal.org/knowledge-center/publications/

[10] Chabra, T.N. \& Kaur, H. (2015). Corporate Governance and Social Responsibility. New Delhi: Sun India Publications

[11] Economic and Social Commission for Asia and the Pacific (2009).Creating Business and Social Value: The Asian Way to Integrate CSR into Business Strategies. Available at http://www.unescap.org/our-work/trade-investment

[12] Environment Management Center (2005). Research Capsule: The Status of Corporate Social Responsibility in India- A Note. Available at www.coprocem.com/documents/12corporate social responsibility.pdf

[13] Gautam, R. \& Singh, A. (2010). Corporate Social Responsibility Practices in India: A study of top 500 companies. Global Business and Management Research 2(1). Available at www.gbmr.ioksp.com/pdf/Gautam\%20\&\%20Singh,\%202010.pdf

[14] Kumar, A. \& Arora, J.R. (2015). Corporate Governance, Business Ethics and CSR. New Delhi: International Book House Pvt. Ltd.

[15] Sharma, J. P. (2013). Corporate Governance, Business Ethics \& CSR. New Delhi: Ane Books Pvt. Ltd. 